\title{
Exploring the Impact of Procurement Policies, Lifecycle Analyses and Supplier Relationships on the Integration of Sustainable Procurement in Public Sector Organisations: A Sub-Saharan African Country Context
}

\author{
Victor O. Adebayo \\ Westminster Business School \\ University of Westminster \\ London United Kingdom
}

\begin{abstract}
The incorporation of sustainability in public sector procurement is increasingly gaining traction globally. Numerous studies have explored the implantation of sustainability into public procurement frameworks, nonetheless, on the whole, there is paucity of empirical research conducted on the embedding and application of sustainability into public sector procurement in SubSaharan African (SSA) countries. This research study integrates the measurement of the impact of procurement policy, lifecycle analysis (LCA), procurement processes and supplier relationships on the implantation of sustainability in state procurement models in a SSA country context. The study utilised a triangulation method by incorporating both quantitative and qualitative research methodologies. Results were attained from questionnaire items sent to 103 respondents working in procurement departments in the Nigerian public sector. In total, a 57\% response rate was achieved. The study also conducted semistructured interviews with 10 procurement workers in the Nigerian public sector. The findings show that, aggregately, there are inadequate policy constructs to embed sustainability in public procurement. The paper recommends that governments in in SSA formulate and implement procurement policies that takes into cognizance the importance of sustainability and also set up processes that will induce an archetypal shift that inculcates greater sustainability awareness and performance.
\end{abstract}

\section{Introduction}

There is an emergent cognizance that the current path of human consumption and diminution of the earth's ecosystem is unmaintainable. There is a growing awareness that commercial profit should not be at the expense of the people or planet [1]. T. Johnsen, M. Howard and J. Miemczyk [2] posited that the planet's resources are in decline and the climate is changing, leading to pressures on businesses to embark on de-carbonisation initiatives, recycling and the development of greener technologies. In the public sector, there is an increased awareness that governments have a role to play in fostering sustainability by a) leading by example and b) articulating and effecting policies that will drive sustainability goals in the society. S. Brammer and $\mathrm{H}$. Walker [3] highlight the importance of policy and GPP policy; K.

Nijaki and G. Worrel [4] posited that GPP policy can stimulate social equity, economic development and create environmental benefits.

In 2015, the Nigerian government will spend around $20 \%$ of its national budget on public procurement, this is an equivalent of $\$ 10$ billion. In the $\mathrm{EU}$, public procurement accounts for $16 \%$ of GDP, in the UK, $31 \%$ of GDP is spent on GPP while the Netherlands, South Korea and the USA spend $45 \%, 40 \%$ and $28 \%$ of GDP respectively on GPP [5]. In view of this indicatory large volume of government expenditure on public purchases, this paper argues that a well formulated GPP policy can facilitate the incorporation of sustainability in economies, especially in developing countries.

\section{Review of Literature}

\subsection{Procurement policy}

In an assessment of the process of developing a Green Public Procurement (GPP) criteria at a Swedish government department, B. C, S. Hallstedt, Broman and Oldmark [6] opined that in other to allow for a more strategic approach that will significantly promote innovative service solutions in support of sustainable development, policy and process changes are needed. Simcoe and Toffel [7] posited that public sector procurement policies may influence private sector demand for similar products; in a study of municipal policies in California, USA, they concluded that government procurement policies facilitate spill-over effects that stimulate, a) private sector adoption and b) supplier investment in green building expertise. 
Researchers [8] argued that due to some distinctiveness within some sectors such as the heritage industry, policy makers and practitioners need greater understanding of the requirements of SME suppliers in different sectors.

\subsection{Lifecycle analysis}

Perera et al. [9] described Lifecycle Analysis (LCA) as economic assessment considering all projected significant cost flows over a period of analysis expressed in monetary terms. LCA enables governments to demonstrate that procurement decisions and activities need to move beyond the consideration of the purchase price of a good or service but examine the costs over the phases of the asset lifecycle. Tysseland [10] in a research study of public procurement by the Norwegian defense ministry observed that there is a policy statement that indicates when procurement decisions are made, purchases that yield the lowest possible lifecycle cost (LCC) for the ministry must be procured, even if the initial cost is higher. S. Hart, [11] explained that in Europe, the European Union (EU) procurement directives of 2014 favor a lifecycle approach for public purchases, however, they do not require cradle-to-grave assessment of environmental impacts. Tarantini et al. [12] opined that LCA facilitates the identification of the main impacts and critical processes of the window lifecycle in Italy, this gives a scientific framework to discuss the sustainability specific criteria with suppliers.

\subsection{Procurement process}

According to Vatalis et al. [13], the main problem of GPP in Greece is related to the waste in processes and the lack of quality specifications. [14], agreed with researcher [13], the paper explained that public procurement regulation such as tender processes may hinder innovation through its rigidity. Smith et al. [15] argued that there is a need for political continuity that supports and enables policy makers and practitioners to take an incremental approach to change. Testa et al. [16] found that raising awareness on GPP techniques can strongly support the development of public tenders and also by national and local supporting initiatives.

\subsection{Partnership and supplier relationships}

Grudinschi et al. [17] postulated that well managed partnerships between buyers and suppliers are needed to achieve collaboration fluency and improve the effectiveness of procurement, the study concluded that in collaborative relationships in public procurement, the higher the perceived relationships, the more positive effects they will have in terms of increasing trust, communication and the quality of collaboration management. Vesalainen and Kohtamäki [18] formulated a parsimonious framework for relationship integration to create a holistic understanding of relational configurations. The paper through empirical research demonstrated the link between relational alignments and performance. Jost et al. [19] observed that the UK public sector increasingly requires private sector organisations to form supplier groupings, especially for large projects. The paper identified the following factors as the main determinants of productive relationships; a) reconciliation of objectives; b) continuity of staff engagement; c) team building; and d) trust.

\section{Methodology}

On the basis of the foregoing literature review, a questionnaire was developed to collect primary data applicable to the outlined objectives of this research. The study utilised a cross-sectional field survey. The questionnaires were circulated to 103 procurement professionals operating in Nigerian public sector organisations. In total, 59 responses were received, representing a $57 \%$ response rate. 11 of the questionnaires were incomplete and were therefore omitted from the data analysis.

In order to increase validity and reliability, semistructured interviews were also conducted. 10 of the respondents agreed to be interviewed for the study and interviews were conducted to gain further insight in terms of the key variables measured in the questionnaire.

\section{Quantitative Results}

\subsection{Questionnaire Respondents}

An overview of the respondents are as follows:

$72.92 \%$ of the respondents indicated that they are Procurement Officers/Analysts, $16.67 \%$ hold the position of Manager, while $6.25 \%$ indicated that they are at the Graduate/Entry level.

$47.92 \%$ of the survey participants work in a local government office, $43.75 \%$ indicated that they work in State government ministry while $4.17 \%$ work in government parastatals.

$70.83 \%$ of the respondents were male while $29.11 \%$ were female.

Sustainability policy and employee experience

When respondents were asked if they have a sustainability policy, $83.3 \%$ indicated they do not have a sustainability policy while $16.67 \%$ indicated they have one. 
$54.17 \%$ of the respondents indicated that they have no experience in sustainable procurement while $59.57 \%$ of the survey participants stated that they have not undergone any training or participated in any educational programme relating to sustainable procurement.

\subsection{Lifecycle analysis and sustainability embedding}

The research measured how sustainability is incorporated into the organisations' of the participants. This category had a mean range between 2.67-2.85. Table 1 shows the mean and standard deviation for the factors measured in the data analysis. Respondents were asked if their organisations use LCA to evaluate the sustainability of goods and services, $58.3 \%$ indicated that this did not happen in their organisations; $10.4 \%$ indicated that it does occur in their organisation but there was no consistency; $18.8 \%$ said that it usually occurs but it could be better. The survey participants were also asked if their organisations asks suppliers to commit to waste reduction goals, $39.6 \%$ said that it does not happen while $18.8 \%$ said that it happens occasionally but there was no consistency. Furthermore, the survey also enquired if organisations asks suppliers to pay the minimum wage for workers, $39.6 \%$ indicated that it did not happen, $20.8 \%$ said that it did happen but there is no consistency.

Table 1. Variable ratings for LCA and the embedding of sustainability

\begin{tabular}{|l|c|c|c|}
\hline & $\boldsymbol{n}$ & $\boldsymbol{x}$ & Std.D \\
\hline $\begin{array}{l}\text { Uses a lifecycle } \\
\text { analysis to } \\
\text { evaluate the } \\
\text { sustainability of } \\
\text { goods/services }\end{array}$ & 48 & 2.79 & 1.15 \\
\hline $\begin{array}{l}\text { Asks suppliers to } \\
\text { commit to waste } \\
\text { reduction goals }\end{array}$ & 48 & 2.85 & 1.26 \\
\hline $\begin{array}{l}\text { Asks suppliers to } \\
\text { pay minimum } \\
\text { wage for workers }\end{array}$ & 48 & 2.83 & 1.27 \\
\hline $\begin{array}{l}\text { Active role in } \\
\text { managing } \\
\text { capital/project } \\
\text { spend }\end{array}$ & 48 & 2.73 & 1.17 \\
\hline $\begin{array}{l}\text { Contribute to risk } \\
\text { assessments on } \\
\text { capital/project } \\
\text { spend }\end{array}$ & 48 & 2.67 & 1.28 \\
\hline
\end{tabular}

\subsection{Procurement Policy}

This section measures the organisations' procurement objectives and how they are developed.

As can be seen from Table 2, the mean range for this category is $2.65-3.23$. The results show that $37.5 \%$ of the participants indicated that their organisations do not have a formal procurement strategy or policy. $22.9 \%$ indicated that their organisations have a procurement strategy policy but lacked consistency. The survey also sought to establish if the participant's organisations' periodically review and update their policies, $33.3 \%$ of the respondents indicated that they did not; $12.5 \%$ indicated that it was the recognized way they do business while $22.9 \%$ indicated that they were not consistent. The research was also interested in establishing if organisations in the Nigerian public sector have a robust procurement data repository; $68.8 \%$ of the participants said this was not the case while $12.5 \%$ said that it occasionally happens but there is no consistency.

Table 2. Variable ratings for procurement policy

\begin{tabular}{|l|l|l|l|}
\hline & $\boldsymbol{n}$ & $\boldsymbol{x}$ & Std.D \\
\hline $\begin{array}{l}\text { Formal procurement strategy and } \\
\text { policy }\end{array}$ & 48 & 3.23 & 1.19 \\
\hline $\begin{array}{l}\text { Periodic review and update of } \\
\text { policy }\end{array}$ & 48 & 3.1 & 1.37 \\
\hline $\begin{array}{l}\text { Systems/processes to monitor } \\
\text { department operating costs }\end{array}$ & 48 & 2.98 & 1.36 \\
\hline $\begin{array}{l}\text { Supplier appraisal/monitoring } \\
\text { system }\end{array}$ & 48 & 2.98 & 1.33 \\
\hline Clear objectives and KPIs & 48 & 3.1 & 1.26 \\
\hline
\end{tabular}

\subsection{Procurement process}

This factor measures how effectively the procurement is run in the participant's organisations. As may be seen in Table 3, the mean range is between 2.85 to 3.06. The participants were asked if their organisations' measure the effectiveness of their procurement performance, $35.4 \%$ indicated that it did not happen while the same number of respondents indicated that while it happens occasionally, there is no consistency. The survey also enquired if the organisations' measure the effectiveness of key procurement processes, $43.8 \%$ indicated that it did not happen while $29.2 \%$ said that it was not consistent; $6.3 \%$ of the respondents indicated that it is a key part of their organisation's procurement culture. When the survey enquired if the organisations benchmark their procurement efficiency and effectiveness, $50 \%$ of the respondents said that it did not happen; $20.8 \%$ indicated that it is not consistent; $12.5 \%$ indicated that although it does happen, it could be better. 
Table 3. Variable ratings for procurement process

\begin{tabular}{|l|c|c|c|}
\hline & $\boldsymbol{n}$ & $\boldsymbol{x}$ & Std.D \\
\hline $\begin{array}{l}\text { Identification of key } \\
\text { procurement } \\
\text { processes critical to } \\
\text { meeting procurement } \\
\text { objectives }\end{array}$ & 48 & 3.04 & 1.24 \\
\hline $\begin{array}{l}\text { Measure effectiveness } \\
\text { of key procurement } \\
\text { processes }\end{array}$ & 48 & 2.96 & 1.21 \\
\hline $\begin{array}{l}\text { Measure effectiveness } \\
\text { of procurement } \\
\text { performance }\end{array}$ & 48 & 3.21 & 1.26 \\
\hline $\begin{array}{l}\text { Responsibility for } \\
\text { improving } \\
\text { procurement } \\
\text { processes clearly } \\
\text { defined }\end{array}$ & 48 & 3.06 & 1.25 \\
\hline $\begin{array}{l}\text { Benchmark } \\
\text { procurement } \\
\text { efficiency }\end{array}$ & & & 1.26 \\
\hline
\end{tabular}

\subsection{Partnership and Supplier Relationships}

This section measures how organisations create partnership with their suppliers. Table 4 show that the mean ratings for this category. The research sought to establish if the organisations develop and manage its relationship with suppliers in other to create mutuality, $41.7 \%$ of the participants indicated that it did not happen, $35.4 \%$ said that it did happen but there is no consistency.

Table 4. Variable ratings for partnership and supplier relationship

\begin{tabular}{|l|c|c|c|}
\hline & $\boldsymbol{n}$ & $\boldsymbol{x}$ & Std.D \\
\hline $\begin{array}{l}\text { Develop and manage } \\
\text { relationship with } \\
\text { suppliers }\end{array}$ & 48 & 3.04 & 1.22 \\
\hline $\begin{array}{l}\text { Clearly documented } \\
\text { supplier management } \\
\text { policy suppliers' }\end{array}$ & 48 & 3.04 & 1.26 \\
\hline $\begin{array}{l}\text { Ensures socations are operated } \\
\text { in a safe manner }\end{array}$ & 48 & 2.79 & 1.29 \\
\hline $\begin{array}{l}\text { Visit suppliers to } \\
\text { confirm working } \\
\text { conditions data }\end{array}$ & 48 & 2.75 & 1.31 \\
\hline $\begin{array}{l}\text { Procurement } \\
\text { repository }\end{array}$ & & 2.65 & 1.28 \\
\hline
\end{tabular}

The paper also sought to establish if the organisations have a clearly documented supplier management policy, 39.6\% indicated that this was not the case, $25 \%$ said that it lacked consistency while $14.6 \%$ expressed that it did happen but it could be better. The research was also considered if organisations ensure that their suppliers' locations are operated in a safe manner, $47.9 \%$ disagreed, and $18.7 \%$ indicated that although it does happen, there is no consistency.

\subsection{Qualitative Results}

Based on the literature review and the outcome of the quantitative study, the paper included a qualitative study to increase validity and reliability. A series of semi-structured interviews were conducted and ten procurement professionals working in the Nigerian public sector agreed to participate in the study. Interviews took place over the telephone and the duration of the interview was between 25- 40 minutes. Table 5 shows a profile of the interviewees. The interview questions were catalogued into the following themes- LCA, procurement process, procurement policy and supplier relationships.

Table 5. Profile of Interviewees

\begin{tabular}{|c|c|c|}
\hline Interviewee & Role & Organisation \\
\hline A & Director & Federal Government \\
\hline B & Procurement Officer & State Government \\
\hline C & $\begin{array}{c}\text { Procurement } \\
\text { Manager }\end{array}$ & Federal Government \\
\hline D & Procurement Officer & State Government \\
\hline E & Manager & Federal government \\
\hline F & Procurement Officer & Federal Government \\
\hline G & Buyer & Federal Government \\
\hline H & $\begin{array}{c}\text { Procurement } \\
\text { Manager }\end{array}$ & State Government \\
\hline I & Manager & State Government \\
\hline J & Director & Federal Government \\
\hline
\end{tabular}

\subsection{LCA}

The majority of the interviewees posited that LCA was not efficiently rooted in their operations, for example, Interviewee D stated that:

\section{We have tried to incorporate this into our procurement policy and two years ago, this was written into our corporate procurement policy, but in reality, it is not an important aspect when we are considering suppliers or as part of our procurement strategy.}

This concurs with results from the questionnaires but it also highlights how LCA is not an important element in Nigerian public sectors.

In terms of ensuring that suppliers commit to waste reduction, the response by Interviewee $\mathrm{E}$ encapsulates the overall approach by procurement departments in the Nigerian public sector:

When suppliers fill out procurement questionnaires, we do ask some of our suppliers to commit to waste reduction. This depends on the sector; we do this mainly in the agricultural and construction sectors. 
The lack of an ingrained instrument to ensure that suppliers have a waste reduction strategy across the lifecycle of their products and services was a major weakness in the organisations researched.

\subsection{Procurement Policy}

In terms of procurement policy and how it aligns with the embedding of sustainability in public sector organisations in Nigeria especially at the federal level, the interviewees indicated that procurement policy is akin to a regulatory directive driven by the Bureau of Public Procurement (B.P.P).

For instance, Interviewee $\mathrm{F}$ posits that:

There is no predetermined periodic review and update of policy. We have a top-bottom approach, so our policies are influenced form the central body and we just comply with directives.

The lack of decentralization is manifestly clear and this could have an impact on innovation and improvement.

In terms of systems and processes to monitor departmental operating costs, Interviewee $\mathrm{C}$ states that:

We do have processes to monitor department spending so that we stay within allocated budget. However, we do have budget deficits in some financial periods but this is usually in in agreement with federal oversight from the $B P P$.

\subsection{Procurement Processes}

With regards to procurement processes, the interviewees also identify some deficiencies, for instance, Interviewee $\mathrm{C}$ mentioned that his organisation's procurement processes were obsolete and lacks quality. He stated that:

This is an area where we need to think about and develop even further. Some of our procurement policies are outdated and not fit for purpose.

Other key issues that arose was that policies and guidelines were replications from other sources and did not meet the particularity and peculiarity of their own organisation. This is in consonance with the crosssectional study in this paper.

\subsection{Partnership and Supplier Relationships}

When the interviewees were asked if they develop and manage relationships with suppliers, Interviewee F indicated that:

The development of relationships with our suppliers is a core part of our official responsibilities. We develop relationships when we engage them so as to ensure that they have the capacity to deliver the required goods and services.

Most of the interviewees identify the management of supplier relationships after the recruitment stage as a key weakness. The interviewees were also asked if their organisations have a clearly documented supplier management policy and Interviewee B indicated that:

We have a written policy but we have a challenge in implementing them efficiently.

Interview D also posited that:

A lot of staff are not trained on what supplier management entails and there is lack of direction from top management.

In terms of procurement data repository and how the organisations store and use information and data, Interviewee $\mathrm{G}$ stated that:

With the introduction of e-procurement in my department, we now have greater capacity to have accessibility to procurement data. However, the system is not perfect because not all procurement activities have been migrated to the $e$ procurement system.

\section{Discussion}

The factors measuring LCA and the embedding of sustainability into the Nigerian public sector were all < 3.0. This indicates that these factors (see Table I) are not optimally accomplished in the organisations surveyed. Factor 1 (uses LCA to evaluate the sustainability of goods/services) had a mean rating of 2.79; based on this result, the empirical assumption is that in overall terms, procurement departments in the Nigerian public sector do not use LCA in state procurement decision making. There is parallelism between the LCA results in this paper and those obtained from S. Brammer and H. Walker [20] that measured sustainable procurement in the UK public sector. The LCA mean ratings for [20] were 2.71 for services, 2.71 for the health sector and 3.0 for the education sector.

Results from the procurement policy category show that, cumulatively, procurement departments in Nigerian public sector have, to a certain degree, integrated formal procurement strategy and policy into their operations. It also indicates that they do conduct periodic reviews and updates of policy as these two factors had mean ratings of 3.23 and 3.1 respectively. Although, results also show that their supplier appraisal and monitoring systems are sub-optimal with a mean rating <3.0. These results are analogous to conclusions by L. Li and K. [21], they conclude that environmentally responsible public procurement is a driving force in the integration of GPP policy 
instruments. Geiser G. Oruezabala and J. C. Rico [22], suggested that in the process of embedding sustainability in public procurement, new policy rules are created.

Results from the procurement process section indicate that the following factors been relatively embedded in the procurement departments survey; a) identification of key procurement processes critical to meeting procurement objectives; b) measurement of the effectiveness of procurement performance and c) responsibility for improving procurement processes are clearly defined. Conversely, results also indicate that there is sub-optimal performance with regards to benchmarking of procurement efficiency and effectiveness. In support of these argument, [6], posited that there are several weaknesses of public process, including, lack of a clear definition of sustainability objectives and no strategy to prepare for future processes. Likewise, [13] revealed that the main problem of GPP in Greece is related to a waste in processes.

Table IV shows that procurement departments have not optimized supplier relationships. Results indicates an aggregate weakness in the following factors; a) procurement departments ensure that suppliers' locations are operated in a safe manner; b) visit suppliers to confirm working conditions and c) procurement data repository, with mean ratings of 2.79 , 2.75 and 2.65. These factors are key elements in the embedding sustainability (in terms of the economic and social aspects of the TBL) in organisations. These results show congruity with conclusions made by Igarashi, Mieko, L. d. Boer and O. Michelsen [23], which concluded that purchasing organisations do not adequately define sustainability criteria when communicating with suppliers and during supplier selection.

The qualitative element of the study provided further insight and allowed for deeper scrutiny. In terms of LCA, the majority of the interviewees posited that LCA was not efficiently rooted in their operations, for example, Interviewee D stated that:

Operationally, we do not use a LCA approach to evaluate the sustainability of goods and services. Much has been said about the importance of LCA but generally, my department sees it as a distraction and not a key part of our strategy or operations.

This affirmation corresponds with results from the questionnaires administered for this paper but it also highlights how LCA is not perceived as an important element in procurement practice in the Nigerian public sector.

In terms of ensuring that suppliers commit to waste reduction, the response by Interviewee $\mathrm{J}$ captures the overall attitude in public sector organisations in Nigeria- based on the responses from the semi- structured interviews and also the questionnaires administered. The interviewee states that:

We only go by their responses on the questionnaire forms that we provide, we do not have any mechanism in place to actually ensure that they have a waste reduction policy in place.

The lack of an entrenched mechanism in ensuring that suppliers have a waste reduction policy is a major challenge in the organisations researched. With respect to procurement policy and how it aligns with the incorporation of sustainability in public sector organisations in Nigeria, the interviewees indicated that procurement policy in their departments is analogous to a regulatory framework that intrinsically has a topbottom approach. The lack of decentralization is clear and has an effect on innovation and improvement.

In terms of partnership and supplier relationships, the interviewees identify the management of suppliers after recruitment as a key weakness. Illustratively, interviewee $\mathrm{J}$ explains that:

This is where we have key weaknesses, we do not have a broad monitoring framework in place. Most monitoring exercises are conducted on an ad hoc basis which is essentially reactive. This has led to a lot of project and procurement failures in my department.

In terms of procurement processes, there is also an identification of some paucities, for instance, there were references to the fact that the processes are outdated and not fit for purpose. Other key issues that came up were that the policies and guidelines were replications and did not meet the particularity and peculiarity of their departmental requirements. This is also in consonance with the quantitative results in this paper.

Crucially, the results from the interviews shows significant imperfections and insufficiencies in the area of benchmarking of procurement efficiency. Most of the interviewees in this study shared the view that since the policy and frameworks were developed in conjunction with the World Bank, it meant that it was efficient and adhered to best practice. However, these processes, policies and frameworks were instituted in 2007, which is about nine years ago. In business terms, this will be considered obsolete and will need to be updated to keep up with changes and improvements in policy.

\section{Conclusion, Limitations and Future Work}

This paper contributes to and enhances the body of literature relating to the embedding of sustainability in public procurement, particularly in developing countries. The paper also contributes to the concepts of procurement policy/process in the public sector and developing countries literature. At practitioner level, 
this research will allow public procurement professionals to further understand how procurement processes can be amplified and how to enhance and augment supplier relationships that are not only symbiotic but provides opportunities for longer term exchanges which will allow for the embedding of sustainability criteria in contracts. The paper also highlights the significance of LCA and how its inclusion in public procurement can provide sustainability benefits. Additionally, in terms of policy, the study will enable governments especially in developing countries to formulate and implement GPP policies and coordinate the embedding of sustainability into public procurement. However, the paper has some limitations, it may be argued that the population of survey was low. The paper utilised a mixed research method which included a cross-sectional quantitative method and semi-structured interviews. It may be debated that the population of the survey participants and interviewees was low and does not adequately represent the overall population of the Nigerian public sector. For further research on this paper, the author proposes that a wider population data is utilised to increase reliability.

\section{Recommendations}

Based on the findings of this research paper, the main recommended actions are as follows:

1. The paper recommends that the government formulates and implements a procurement policy that recognizes the importance of sustainability and one that will induce an archetypal shift that inculcates greater sustainability awareness.

2. There should be greater focus and possibly the use of regulations and directives to ensure that LCA is incorporated in Nigerian public procurement policy.

3. It is important there is a more proactive approach towards supplier relationship management, one that goes further than just supplier engagement but also actively enhances supplier management over the contract lifecycle and a smart monitoring mechanism leading to improved supplier performance that ultimately optimizes sustainability objectives.

4. Efforts should be made to decentralize procurement control that will enable specificity in terms of solutions that meet strategic procurement requirements.

5. There should be increased standardization and harmonization across the procurement function in the Nigerian public

\section{References}

[1] P. Jacques, "Sustainability: The Basics, Routledge, 2014.
[2] T. Johnsen, M. Howard and J. Miemczyk, Purchasing and Supply Chain Management: A Sustainability Perspective, Routledge, 2014.

[3] S. Brammer and H. Walker, "Sustainable procurement in the public sector: an international comparative study," International Journal of Operations \& Production Management, vol. 31, no. 4, pp. 452-476., 2011.

[4] K. Nijaki and G. Worrel, "Procurement for sustainable local economic development.," International Journal of Public Sector Management, vol. 25, no. 2, pp. 133-153., 2012.

[5] V. Adebayo, "Embedding Sustainability in the Public Procurement Framework of Developing Countries- An Empirical Analysis of the Lagos State Government," Journal of Economics and Sustainable Development, vol. 6, no. 18, pp. 114-125, 2015.

[6] B. C, S. Hallstedt, Broman and Oldmark, "Assessment for criteria development for public procurement from a startegic sustainability perspective," Journal of Cleaner Production, vol. 52, pp. 309-316, 2013.

[7] Simcoe and Toffel, "Government green procurement spillovers: Evidence from municipal building policies in California," Journal of Environmental Economics and Management, vol. 68, no. 3, pp. 411-434, 2014.

[8] Loader and Norton, "SME access to public procurement: An analysis of the experiences of SMEs supplying the publicly funded UK heritage sector," Journal of Purchasing and Supply Management., 2015.

[9] O. Perera, B. Morton and T. Prefrement, "Lifecycle Cost in Sustainable Public Procurement: A question of Value," International Institute of Sustainable Development, Manitoba, Canada, 2009.

[10] B. E. Tysseland, "Life cycle cost based procurement decisions: a case study of Norwegian defence procurement projects," International Journal of Project Managemen, vol. 26(4), pp. 366-375, 2008.

[11] S. Hart, "Green" Product Procurement Policy in the European Union: Treatment of Lifecycle Carbon Analysis and Environmental PPM Restrictions," Columbia Law School, Sabin Center for Climate Change Law, 2013.

[12] M. Tarantini, A. D. Loprieno and P. L. Porta, "A life cycle approach to Green Public Procurement of building materials and elements: A case study on windows," Energy, vol. 36, no. 5, pp. 2473-2482, 2011.

[13] Vatalis, Manoliadis and Mavridis, "Project performance indicators as an innovative tool for identifying sustainability perspectives in green public procurement," Procedia Economics and Finance, vol. 1, pp. 401-410, (2012).

[14] Haavisto and Kovács, "A Framework for Cascading Innovation Upstream the Humanitarian Supply Chain through Procurement Processes," Procedia Engineering, vol. 107, pp. 140-145., 2015. 
[15] J. Smith, G. Andersson, R. Gourlay, S. Karner, B. E. Mikkelsen, R. Sonnino and D. Barling, "Balancing competing policy demands: the case of sustainable public sector food procurement," Journal of Cleaner Production, 2015.

[16] Testa, Annunziata, Iraldo and Frey, "Drawbacks and opportunities of green public procurement: an effective tool for sustainable production," Journal of Cleaner Production, 2014.

[17] Grudinschi, Sintonen and Hallikas, "Relationship risk perception and determinants of the collaboration fluency of buyer-supplier relationships in public service procurement.," Journal of Purchasing and Supply Management, vol. 20, no. 2, pp. 82-91., 2014.

[18] Vesalainen and Kohtamäki, "Toward a typological view of buyer-supplier relationships: Challenging the unidimensional relationship continuum," Industrial Marketing Management., 2015.

[19] Jost, Dawson and Shaw., "Private Sector Consortia Working for a Public Sector Client-Factors that Build Successful Relationships:: Lessons from the UK.," European Management Journal, vol. 23, no. 3, pp. 336-350., 2005.

[20] S. Brammer and H. Walker, "Sustainable procurement in the United Kingdom public sector," Supply Chain Management:An International Journal,, vol. 14, no. 2, pp. 128-137., 2009.

[21] L. Li and K. Geiser, "Environmentally responsible public procurement (ERPP) and its implications for integrated product policy (IPP)," Journal of Cleaner Production, vol. 13, no. 7, pp. 705-715, 2005.

[22] G. Oruezabala and J. C. Rico, "The impact of sustainable public procurement on supplier management - The case of French public hospitals," Industrial Marketing Management, vol. 41, no. 4, pp. 573-580., 2012.

[23] Igarashi, Mieko, L. d. Boer and O. Michelsen, "Investigating the anatomy of supplier selection in green public procurement," Journal of Cleaner Production, 2015.

[24] BudgIT, "Nigeria Budget data," 2015. [Online]. Available: //www.yourbudgit.com/data/. [Accessed 2 March 2015].

[25] Senge, Smith, Kruschwitz, Laur and S. ., "The Necessary Revolution: How Individuals andOrganizations Are Working Together to Create a Sustainable World. Strategic Direction," vol. 25 , no. $8,2009$.

[26] OECD, "Public procurement spending", in OECD, Government at a Glance 2013", OECD, Paris, 2013.

[27] C. McCrudden, "Using public procurement to achieve social outcomes. In Natural resources forum," Blackwell Publishing Ltd., vol. 28, no. 4, pp. 257-267, 2004.
[28] OECD, "“Size of public procurement spending"," 2014. [Online].Available: http://www.oecd-ilibrary.org/sites/gov_ glance-2011 en/09/01/index.html?contentType=/ns/Statistical Publication/ns/Chapter\&itemId=/content/chapter/gov_glance2011-46-en\&containerItemId=/content/serial/22214399\& accessItemIds $=\&$ mimeType $=$ text $/$ html. $\quad[$ Accessed 12 